\title{
PEMANFAATAN INTERNET SEBAGAI MEDIA AKSES INFORMASI \\ DALAM KONTEK HMC (Handphone Mediated Communication) DI KALANGAN MAHASISWA UIN STS JAMBI
}

\author{
MUHAMMAD RUM \\ rummuhammad71@gmail.com
}

FAKULTAS ADAB DAN HUMANIORA UIN SULTHAN THAHA SAIFUDDIN JAMBI

\begin{abstract}
This article aims to know the internet exploiting through handphone media to access informtion that used by the students of the state Islamic university Sulthan Thaha Saifuddin of Jambi. This result of research has depicted that; firstly, the orient of students in exploiting handpone in framework of self development ; to support the academic activity ( lesson and research), to add the knowledge, experience, and pass the time with the entertainment amusement information. Secondly, the students's motivation of the state Islamic university Sulthan Thaha Saifuddin of Jambi in exploiting internet as communications media include; inquiring motif namely motivation to know the new things can add knowledge, to think sistimaticly, to have construction idea, and to add the empirical experience; to motivate to compet profesionally and percepcionist, to have effectivness learning method; to have social integration and to get appreciation from academic society. Thirdly, the students's target to exploit handphone as communications media are; diversion namely to secede from some problems, medium of emotion release; personal relationship namely friendship, social benefit, wide assocciation, firmness contact with the family and others; personal identity namely x'self reference, eksplorasi reality, reinforcement assess, wish to strengthen the self identity, belief, individual status and stability. Fourthly, Form and method of information seeking by student through handphone as communications media through article, PDF, while browsing machine is used generally the Google and Yahoo. The browsing is done only download. Finally, the students's expectation in exploiting internet for the ptoses of x'self development are; good behaviour namely appearance of student behaviour which like to read, like to discuse to hit the knowledge dynamics in so many angle; corner, to investigate the truth performing of research, like the loran or solitary than talking with others in fad.
\end{abstract}

Key Word: Handphone, Internet, prilaku.

\section{A. PENDAHULUAN}

Fenomena pencarian informasi (information seeking) di kalangan masyarakat melalui handphone telah booming sejak munculnya beberapa aplikasi yang ditengarai mempermudah untuk mengakses informasi dalam berbagai aspek. Pola pencarian informasi tidak saja dalam kontek kebutuhan komunikasi verbal antar personal, tetapi juga kebutuhan kerja, profesi dan bisnis. Kehadiran handphone yang didukung dengan berbagai aplikasi komunikasi menyebabkan pola pencarian informasi di kalangan masyarakat semakin efektif dan efisien. Menurut Cai K dan Zhang bahwa perkembangan teknologi informasi, perubahan

\footnotetext{
- Ketua Program Studi Ilmu Perpustakaan dan Informasi FAH UIN Sulthan Thaha Saifuddin Jambi
} 
social ekonomi serta perbedaan model interaksi menyebabkan pe rubahan cara mengakses dalam menggunakan informasi. ${ }^{1}$

Hasil survei menunjukkan bahwa penggunaan media handphone untuk akses informasi di kalangan masyarakat Indonesia tahun 2016 mengalami perbedaan yang cukup siginifikan dengan media lain. Penelitian ini menunjukkan bahwa penggunaan handphone sebagai media untuk mengakses informasi tidak saja digandrungi oleh kalangan masyarakat ekonomi atas, tetapi juga pada masyarakat ekonomi bawah, namun yang membedakan hanya penggunaan dan kebutuhan informasi. Berikut tabel penggunaan media komunikasi oleh masyarakat Indonesia tahun 2016.

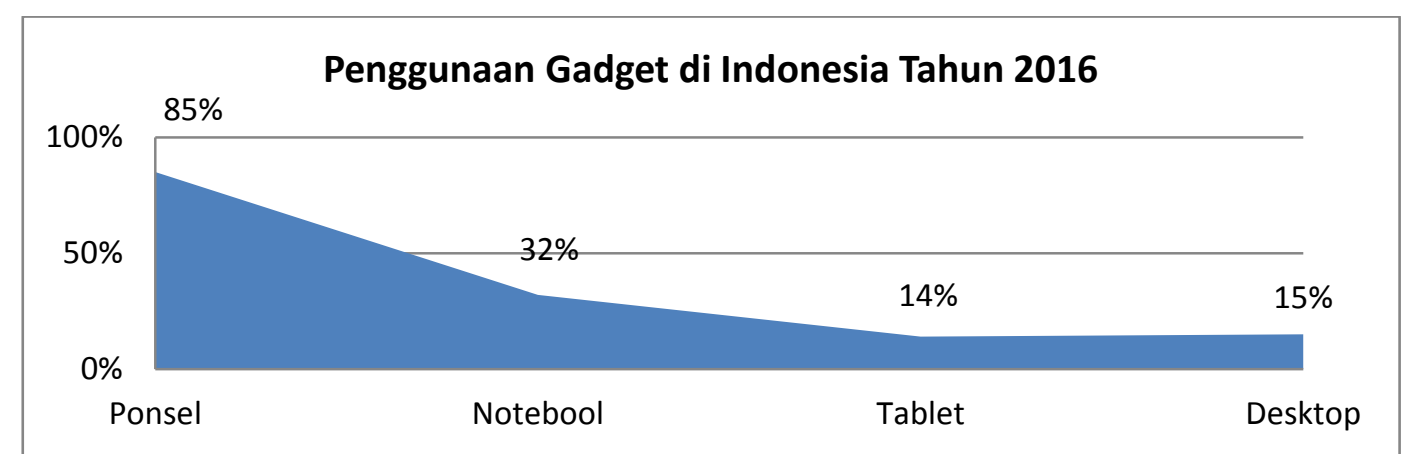

Sumber : https://www.goodnewsfromindonesia.id/2016/01/21

Berdasarkan tabel di atas menunjukkan bahwa handphone (ponsel) merupakan media yang paling digandrungi oleh masyarakat Indonesia. Selain itu, kehadiran situs lokal seperti detikcom, Liputan6, Kaskus, BukaLapak, dan Kompas.com. cukup mewarnai pola akses informasi masyarakat meskipun masih kalah bersaing dengan peringkat 5 terpopuler yang seluruhnya didominasi oleh situs-situs luar negeri seperti Google, Facebook, Youtube, Yahoo!, dan Wordpres.

Di lingkungan perguruan tinggi, prilaku akses informasi khususnya di kalangan mahasiswa penggunaan media handphone bukan lagi sebagai kebutuhan sekunder dalam mendukung proses berkomunikasi, tapi berubah menjadi kebutuhan primer. Pola komunikasi itu ditunjukkan dalam proses perkuliahan melalui akses informasi sumber-sumber informasi ilmiah, bibliografi dalam berbagai bentuk. Perubahan-perubahan tersebut membawa konsekuensi terhadap prilaku belajar mahasiswa.

\footnotetext{
${ }^{1}$ Cai , K. and Zhang, C. Towards a Research on Information Pollution. Proceedings of the IEEE International Conference on Systems, Man, and Cybernetics, 1996, hlm. 3124 - 3129
} 
Tulisan ini akan menggambarkan secara sederhana mengenai penggunaan media handphone dikalangan mahasiswa dalam berprilaku mengakses informasi keseharian.

\section{B. Kajian Teori}

\section{Pengertian Internet dan Handphone}

\section{a. Internet}

Abdul Kadir menggambarkan internet adalah salah satu media komunikasi yang populer, dan disukai oleh para pencari informasi dikarenakan akses yang cepat dan data yang akurat serta selalu up to date. ${ }^{2}$

Sementara Reddick dan King mendefinisikan internet sebagai suatu istilah yang digunakan untuk menggambarkan saling hubungan antar jaringan-jaringan komputer sedemikian rupa, sehingga memungkinkan komputer-komputer itu saling berkomunikasi satu sama lain. ${ }^{3}$

Selanjutnya, Naisbit mengemukakan beberapa keunggulan dari media internet:

1) Mudah. Internet menyajikan berbagai kemudahan bagi user untuk mengoperasikannya. Dengan program windows user hanya perlu untuk mengklik tombol (simbol sesuai kebutuhan dan berbagai aplikasi sudah dapat dijalankan). Begitu pula untuk aplikasi lainnya, bila dibandingkan dengan pemakaian fax dalam pengiriman data/tulisan.

2) Cepat dan Tepat. Pengiriman data melalui internet berlangsung dengan cepat karena langsung dikirim dari komputer ataupun dari disket, sehingga langsung dikirim dalam bentuk pulsa-pulsa (data). Berbeda dengan fax, yang menggunakan sistem pelarikan cahaya, membutuhkan waktu sekitar 1 (satu) menit untuk me-ngirim satu halaman.

3) Kapasitas. Free Space/ruang yang tersedia untuk mail box yang disiapkan bagi tiap-tiap user oleh tiap web site tidak sama.

4) Kerahasiaan. Setiap user/pemakai yang terdaftar untuk menjadi pelanggan internet akan mendapat fasilitar password. Baik password untuk mengakses internet maupun password yang diprogram untuk mengoperasikan komputernya. Begitu pula dengan free space (mail box) yang disediakan kepada user/pemakai pada suatu web site, hanya dapat diakses/pemilik alamat.

\footnotetext{
${ }^{2}$ Kadir, Abdul. Pengenalan Sistem Informasi. (Yogyakarta: Andi, 2006), hlm. 42

${ }^{3}$ Reddick, Randy and King Elliot. Internet untuk Wartawan: Internet untuk semua Orang.

(Jakarta: Yayasan Obor Indonesia, 1996), hlm. 76
} 
5) Efisien dan Efektif. Pemakaian pulsa oleh peralatan fax sangat dipengaruhi oleh jarak. ${ }^{4}$

Dengan keunggulan yang dipaparkan oleh Naisbit di atas menunjukkan bahwa internet dengan segala fasilitas yang disediakan memberikan efek prilaku setiap indidvidu yang mengakses informasi. Prilaku akses informasi di kalangan mahasiswa dengan menngunakan media handphone berimpak pada prilaku belajarnya, misalnya cenderung bersikap prgamatis, pelanggaran terhadap kode etik akademik misalnya plagiat, menururnnya daya fikir dan hubungan silaturrahmi yang semakin berkurang, tidak pekanya terhadap lingkungan sosial.

Sementara menurut Choo, Detlor, \& Turnbull bahwa terdapat empat mode dalam kegiatan penemuan informasi melalui internet, ${ }^{5}$ diantaranya adalah:

\section{1) Undirected viewing}

Pada undirected viewing, seseorang mencari informasi tanpa tahu informasi tertentu dalam pikirannya. Tujuan keseluruhan adalah untuk mencari informasi secara luas dan sebanyak mungkin dari beragam sumber informasi yang digunakan, dan informasi yang didapatkan kemudian disaring sesuai dengan keinginannya.

\section{2) Conditioned viewing}

Pada conditioned viewing, seseorang sudah mengetahui akan apa yang dicari, sudah mengetahui topik informasi yang jelas, Pencarian informasinya sudah mulai terarah.

\section{3) Informal search}

Mode informal search, seseorang telah mempunyai pengetahuan tentang topik yang akan dicari. Sehingga pencarian informasi melalui internet hanya untuk menambah pengetahuan dan pemahaman tentang

\footnotetext{
${ }^{4}$ Naisbitt, John. High Tech High Touch: Pencarian Makna di Tengah Perkembangan Pesat Teknologi. (Bandung: Mizan, 2001)

${ }^{5}$ Choo, Detlor, \& Turnbull. Working the Web [microform] : An Empirical Model of Web Use. Microfiche. ([Washington D.C.]: ERIC Clearinghouse microfiches, 1999)
} 
topik tersebut. Dalam tipe ini pencari informasi sudah mengetahui batasanbatasan sejauh mana seseorang tersebut akan melakukan penelusuran. Namun dalam penelusuran ini, seseorang membatasi pada usaha dan waktu yang ia gunakan karena pada dasarnya, penelusuran yang dilakukan hanya bertujuan untuk menentukan adanya tindakan atau respon terhadap kebutuhannya.

\section{4) Formal search}

Pada formal search, seseorang mempersiapkan waktu dan usaha untuk menelusur informasi atau topik tertentu secara khusus sesuai dengan kebutuhannya. Penelusuran ini bersifat formal karena dilakukan dengan menggunakan metode-metode tertentu. Tujuan penelusuran adalah untuk memperoleh informasi secara detail guna memperoleh solusi atau keputusan dari sebuah permasalahan yang dihadapi.

\section{b. Handphone}

Istilah handphone berasal dari kata hand dan phone yakni tangan dan telepon yakni telepon tangan. Dalam kamus bahasa indonesia mendefenisikan bahwa handphone adalah pesawat listrik yang berfungsi untuk bercakap-cakap dengan orang lain yang tempatnya berjauhan. ${ }^{6}$

Handphone adalah sebuah perangkat telekomunikasi elektronik yang mempunyai kemampuan dasar yang sama dengan telepon fixed line sehingga konvesional namun dapat dibawa keman-mana (portable) dan tidak perlu disambungkan dengan jaringan telepon menggunakan kabel (nirkabel, wireless). ${ }^{7}$

Menurut Thomas $\mathbf{J}$ dan Misty $\mathrm{E}$ handphone adalah telepon yang menyediakan fungsi asisten personal serta fasilitas internet connection yang bisa menguhubungkan pengguna dengan dunia maya seperti melalui media sosial dan lain-lain. ${ }^{8}$

Berdasarkan pengertian di atas bahwa handphone atau smartphone merupakan media yang mudah dibawa ke mana-mana untuk digunakan

\footnotetext{
${ }^{6}$ Anonim. Kamus Besar Bahasa Indonesia. (Jakarta: Balai Pustaka, 1994), hlm. 279

${ }^{7}$ Yuniar Supardi. Aplikasi Populer Handphone. (Jakarta: Eleks Media Kompetindo, 2009), hlm. 67

${ }^{8}$ Thomas J dan Misty E. Discovering Computer. (Jakarta: Gramedia, 2006), hlm. 271
} 
sebagai media berkomunikasi bagi si pengguna. Kehadiran handphone atau smartphone memberikan efek multi guna bagi konsumen khususnya dalam kontek komunikasi.

\section{Prilaku Akses Informasi sebagai kegiatan Komunikasi}

Perilaku secara sederhana dapat diartikan suatu perbuatan yang dilakukan oleh individu. ${ }^{9}$ Salah satu yang mendasari suatu perilaku, menurut Newcomb, Turner dan Carter adalah sikap. Sikap sangat berpengaruh pada perilaku, akan tetapi masih ada faktor lain yaitu peran situasi lingkungan. Newcomb mengatakan,

"Sikap-sikap membantu menetapkan tingkah laku dalam situasi. Sikap merupakan keadaan-keadaan yang mengantari, sedangkan keadaan sendiri ditentukan oleh keseluruhan situasi masa lampau yang pernah dijalani oleh individu". 10

Berikut model peranan sikap dalam menentukan perilaku :

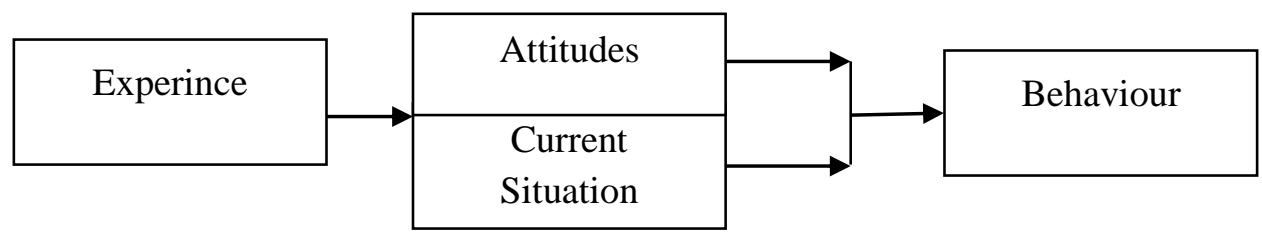

Sedangkan Djaali ${ }^{11}$ mengemukakan bahwa sikap terdiri dari tiga komponen, yaitu emosi, informasi dan perilaku. Komponen emosi merujuk pada kecerdasan emosi yang berpengaruh terhadap perilaku organisasi. menurut Sternberg dalam bukunya Succesfull Intelligence ${ }^{12}$ bahwa jenis-jenis emosi dalam dunia kerja terdiri dari marah, takut, senang, cinta, sedih dan terkejut. Kecerdasan rasional (IQ) hanya memberikan sumbangan $4 \%$ dari keberhasilan dunia nyata. Dengan demikian peran kecerdasan emosi ini semakin besar. Humor yang merupakan bagian dari rasa senang. Humor sejauh ini merupakan perilaku paling menonjol yang menunjukkan

\footnotetext{
${ }^{9}$ Rakhmat, Jalaluddin. Psikologi Komunikasi. Bandung. Remadja Rosdakarya, 1998), hlm. 108

${ }^{10}$ Littlejohn, Stephen W. Theories of Human Communication, ed ke-3. (Belmont, California, Wardsworth Publishing Company, 1989), hlm. 112

${ }^{11}$ Djaali. Psikologi Pendidikan. Jakarta : Bumi Aksara, 2007), hlm. 114

${ }^{12}$ Sptizberg. Brian H. Preliminary Development of a Model and Measure of Computer-Mediated Communication $(C M C)$ Competence. (School of Communication San Diego State University, 2006), hlm. 78
} 
kecerdasan manusia kata Edward deBono, seorang tokoh kreativitas organisasi.

Komponen informasi menyangkut kepercayaan dan informasi individu mengenai suatu objek. Kepercayaan merupakan kekuatan emosi yang dimulai dengan memiliki harga diri dan makna diri sehingga kita terpanggil untuk memancarkan kepada orang lain, seperti jari-jari sebuah lingkaran, yang akhirnya mengimbas kepada setiap orang dalam tim kita, di departemen kita, di devisi kita atau di seluruh perusahaan.

Komponen perilaku terdiri dari kecenderungan orang untuk berperilaku dalam sebuah cara yang khusus terhadap suatu objek. Komponen perilaku terdiri dari motivasi, cara berpikir, cara bertindak dan cara berinteraksi. Teori motivasi Maslow ${ }^{13}$ yang lebih mengutamakan kebutuhan bertahan hidup, yaitu fisiologis, yang berakibat krisis makna yang amat dalam, ketiadaan keyakinan pada apa pun, standar moralitas yang rendah, egoisme yang kejam dan harga diri yang rendah yang merupakan konsekuensinya, ketiadaan tujuan dan nilai, rasa jemu yang menjadi ciri dari sebagian besar kehidupan pada abad 20 di dunia Barat yang maju adalah bukti kuat untuk membalikkan prioritas kapitalisme. Pada akhir hidupnya, Abraham Maslow sendiri merasa bahwa sesungguhnya piramida kebutuhannya terbalik, sehingga kebutuhan yang harus diutamakan adalah kebutuhan aktualisasi diri, yang menjunjung tinggi nilai, standar moral, keyakinan dan kebaikan serta bermanfaat bagi manusia lain.

Motivasi ini mengacu pada hal-hal yang termasuk dalam proses motivasi dalam orientasi masa depan. Motivasi ini berkaitan dengan tujuan yang ingin dicapai di masa depan. Motivasi ini meliputi motif, minat dan tujuan. Menurut Nuttin, bahwa sebagian besar motif, minat dan tujuan individu berorientasi ke masa depan.

\section{Kebutuhan Informasi}

Seorang manusia ketika mencari informasi atau secara tidak langsung berkomunikasi/ interaksi melalui media yang dipilihnya,

\footnotetext{
${ }^{13}$ Op Cit. Djaali. Psikologi Pendidikan, hlm. 116
} 
dipengaruhi oleh motif-motif yang menggerakkan dalam dirinya. Setiap manusia mempunyai alasan untuk memilih apa yang dianggapnya baik. Gerungan mengemukakan beberapa motif yang mempengaruhi perilaku seseorang, yaitu:

a. Motif tunggal, motif bergabung

b. Motif biogenetis

c. Motif Sosiogenetis

d. Motif teogenetis. ${ }^{14}$

Usaha untuk memenuhi dan mencari informasi untuk proses pengembangan diri, individu secara aktif melakukan proses pencarian informasi melalui media komunikasi yang dipilihnya, yang menurutnya mampu memberikan kepuasan dan informasi yang sesuai dengan kebutuhannya. Sulistyo Basuki ${ }^{15}$ mengemukakan bahwa perilaku pemakaian media komunikasi dipengaruhi oleh faktor seperti pendidikan, apakah individu pernah tahu tidak pernah mendapatkan pengajaran cara penggunaan media komunikasi, keteraihan unit informasi, kondisi kerja pemakai, dan waktu yang tersedia untuk mencari informasi, pengalaman individu dan sebagainya.

Kebutuhan informasi merupakan suatu keadaan yang terjadi dalam struktur kognisi seseorang yang dirasakan ada kekosongan informasi atau pengetahuan sebagai akibat tugas atau sekedar ingin tahu. Kekurangan tersebut perlu dipenuhi dengan informasi baru yang sesuai dengan kebutuhannya. Pemenuhan kebutuhan informasi inilah yang mendorong seseorang berinteraksi atau berkomunikasi dengan berbagai sumber informasi untuk mendapatkan informasi yang sesuai dengan kebutuhannya. Dalam interaksi dengan media komunikasi inilah muncul istilah perilaku informasi.

\section{METODOLOGI}

Penelitian ini dilaksanakan di lingkungan mahasiswa UIN Sulthan Thaha Saifuddin Jambi Tahun 2016. Sedangkan pendekatan metode penelitian yang digunakan pada penelitian ini adalah metode deskriptif berupa suatu studi kasus

\footnotetext{
${ }^{14}$ Ibid. Gerungan W.A. Psikologi... hlm. 20

15 Basuki, Sulistyo. Teknologi Komunikasi Dalam Lembaga Informasi dan Perpustakaan. (Jakarta : Gramedia, 1992), hlm. 127
} 
yang bertujuan menjelaskan adanya hubungan ketergantungan individu dengan internet sebagai media komunikasi dalam berkomunikasi dan penggunaan media based handphone. Teknik analisis yang akan digunakan dalam penelitian ini adalah kualitatif, sedangkan pendekatannya adalah fenomenologi ${ }^{16}$ Unit populasi adalah seluruh mahasiswa UIN Sulthan Thaha Saifuddin Jambi. Karena penelitian ini bersifat kualitatif maka penulis menggunakan sampel purposif. Dalam penelitian ini penulis mengkategorikan informan yang termasuk ke dalam informan kunci adalah Pembantu Rektor I selaku pimpinan tertinggi yang diharapkan dapat memberikan izin melakukan penelitian dan dapat memberikan informasi-informasi yang tidak dapat diobservasi langsung, selanjutnya adalah para ketua jurusan yang ada di lingkungan setiap Fakultas UIN Sulthan Thaha Saifuddin Jambi yang mengetahui proses perkuliahan di setiap jurusan, serta dapat memberikan rekomendasi untuk menunjuk mahasiswa yang layak diwawancara. Selanjutnya adalah informan utama yang terdiri dari para mahasiswa di lingkungan UIN Sulthan Thaha Saifuddin Jambi.

Data dikumpulkan melalui observasi, dokumentasi dan wawancara terstruktur dan tidak terstruktur. Analisis kualitatif dalam penelitian komunikasi berangkat dari pendekatan fenomenologi, dengan alasan bahwa analisis fenomenologi lebih tepat digunakan untuk mengurai persoalan subjek manusia yang umumnya tidak taat asas, berubah-ubah dan sebagainya. ${ }^{17}$ Dengan demikian, maka pendekatan analisis kualitatif menggunakan pendekatan logika induktif, di mana silogisme dibangun berdasarkan pada hal-hal yang khusus atau data di lapangan dan bermuara pada hal-hal umum.

\section{PEMBAHASAN}

\section{Orientasi Mahasiswa UIN Sulthan Thaha Saifuddin Jambi dalam mencari informasi baru di internet Melalui Media Handphone}

Sebagai bagian dari masyarakat ilmiah, mahasiswa senatiasa terus berusaha untuk memperdalam dan memperluas pengetahuannya dengan

\footnotetext{
${ }^{16}$ Pendekatan fenomenologi adalah pendekatan yang digunakan oleh peneliti untuk berusaha memahami arti peristiwa dan kaitan-kaitannya terhadap orang-orang yang berada dalam situasisituasi tertentu. (Moleong, 2007:17) fenomenologi memberi tekanan pada verstehen, yaitu pengertian interpretatif terhadap pemahaman manusia.

${ }^{17}$ Ibid. Bungin. hlm. 90
} 
orientasi agar dapat memahami fungsi dan kedudukannya. Untuk mewujdkan demikian maka apsek kognitif sangat berperan penting agar mahasiswa memiliki kepuasan tersendiri. Katz, Gurevitch, dan Haas menyebutkan bahwa kebutuhan kognitif berkaitan dengan kebutuhan memperkuat pengetahuan dan pemahaman orang terhadap lingkungannya. ${ }^{18}$ Kebutuhan ini didasarkan pada hasrat individu untuk memahami dan menguasai lingkungannya. Selain itu kebutuhan ini juga dapat memberi kepuasan atas hasrat keinginan dan penyelidikan individu.

Kegiatan pencarian informasi dapat digolongkan pada kebutuhan kognitif seseorang, yaitu kebutuhan akan informasi tentang lingkungannya, tentang fenomena yang terjadi disekelilingnya dan tentang penambahan pengetahuan-pengetahuan baru. Akhirnya manusia akan mencari dan mencari cara untuk memenuhi kebutuhan kognisinya. Pencarian informasi bisa dilakukan dengan berbagai cara, apakah itu membaca buku, menonton televisi, berdiskusi dengan teman sejawat dan lain-lain. Untuk memenuhi kebutuhan akan informasi seorang mahasiswa biasanya mencari lewat sumber informasi yang bersifat tekstual, seperti buku, majalah ilmiah, jurnal ilmiah dan media cetak lainnya. Tetapi dengan adanya media internet, maka pola pencarian yang lama dengan menggunakan media yang bersifat tekstual mengalami pergeseran. Media lama dianggap terlalu sulit, dan memerlukan waktu serta biaya yang tidak sedikit untuk mendapatkan informasi yang benar-benar sesuai dengan kebutuhan. Selanjutnya pola pencarian lain adalah dengan menggunakan media komputer, namun dianggap tidak efektif karena harus menfokuskan satu tempat dan tidak mudah dibawa-bawa. Akhirnya, kehadiran handphone dianggap sangat efektif bahkan dalam setiap saat dapat dibuka dan mengakses informasi dalam berbagai aplikasi.

Orientasi pemanfaatan media handphone dalam mengakses informasi umumnya mahasiswa lebih pada upaya untuk mempermudah, mengefektifkan waktu dan biaya.

\footnotetext{
${ }^{18}$ Littlejohn, Stephen W. Theories of Human Communication, ed ke-3. (Belmont, California, Wardsworth Publishing Company, 1989), hlm. 191
} 


\section{Motivasi Mahasiswa UIN Sulthan Thaha Saifuddin Jambi dalam mencari informasi baru di internet Melalui Media Handphone}

Komponen perilaku terdiri dari kecenderungan orang untuk berperilaku dalam sebuah cara yang khusus terhadap suatu objek. Motivasi merupakan komponen terpenting dalam sebuah informasi. Motivasi ini mengacu pada hal-hal yang termasuk dalam proses motivasi dalam orientasi masa depan. Motivasi ini berkaitan dengan tujuan yang ingin dicapai di masa depan. Jika boleh disebut motivasi merupakan dorongan atau alasan seseorang bertindak atau berbuat.

Motivasi muncul karena dipengaruhi oleh situasi yang sarat dengan informasi menyebabkan sesorang bertindak sesuai dengan apa yang akan diinginkan. Motivasi untuk bertindak juga dipengaruhi oleh aspek kebutuhan yang mencakup akan aktualisasi diri. Menurut Manullang bahwa motif suatu faktor internal yang menggugah, mengarahkan dan mengintegrasikan tingkah laku seseorang yang didorong oleh kebutuhan, kemauan dan keinginan yang menyebabkan timbulnya suatu perasaan yang kuat untuk memenuhi kebutuhan. ${ }^{19}$

Motivasi peningkatan prestasi akademik bagi mahasiswa UIN STS Jambi melalui pemanfaatan handphone sebagai media komunikasi lebih diarahkan pada motivasi berprestasi yang memiliki standar keunggulan dalam menyelesaiakn tugas-tugas perkuliahannya. Motivasi yang berdasarkan stadar keunggulan yang mencakup prestasi belajar, kemampuan sosial, kemampuan pribadi dan lain-lain seiring dengan tuntutan akademik yang kian komplek. Hampir semua responden yang menyebutkan bahwa motivasi dalam memanfaatkan handphone sebagai media komunikasi adalah untuk merubah metode kegiatan belajar, menambah wawasan agar dalam berprilaku komunikasi lebih efektif, ingin mentahui hal-hal yang baru terkait dengan kegiatan akademik, dan adanya dorongan untuk lebih mengaktualisasikan diri dengan lingkungan kampus.

${ }^{19}$ Rakhmat, Jalaluddin. Psikologi Komunikasi. (Bandung: Remaja Rosda Karya, 1996), hlm. 165 
Dalam teori ketergantungan yang dikemukakan oleh Ball-Rokeach dan De Fleur, bahwa individu akan semakin tergantung pada suatu objek yang ditekuninya, akan semakin memperkuat motivasi seseorang untuk mencapai suatu prestasi. ${ }^{20}$ Fenomena pemanfaatan handphone di kalangan mahasiswa UIN STS Jambi sudah pada tingkat kebutuhan mendasar (urgen), hal ini disebabkan karena tuntutan akademik, ketergantungan teknologi dan persahabatan. Faktor inilah yang mendorong oleh banyak mahasiswa UIN STS Jambi untuk memnafaatkan media ini.

\section{Tujuan Mahasiswa UIN Sulthan Thaha Saifuddin Jambi dalam mencari informasi baru di internet Melalui Media Handphone}

Tidak dapat dipungkiri bahwa sebagai makhluk sosial, manusia senantiasa dipengaruhi oleh kejadian-kejadian sekelilingnya yang dapat mempengaruhi prilaku dan sikapnya untuk memahami dirinya dan orang lain. Griffin menyebutkan dalam Littlejohn bahwa manusia memiliki kebutuhan sosial untuk senantiasa berkembang seiring dengan tingkat kebutuhan yang diinginkan. Kebutuhan ini menurut Griffin disebut sebagai kebutuhan integrasi personal dan integrasi sosial ${ }^{21}$ atau yang sering dikenal dengan istilah kesalehan individu dengan kesalehan sosial.

Kedua kebutuhan ini mengarahkan manusia untuk senantiasa berinteraksi dengan manusia lain, ingin mendapatkan penghargaan dan pengakuan. Dalam kerangka pengembangan diri manusia selalu bergerak dan berfikir mencari pola-pola yang memungkinkan dia dapat menerapkan keinginan dari kebuutuhan tersebut (integrasi personal dan sosial).

Selanjutnya dikatakan oleh Maslow bahwa orang akan diakui dan dihargai apabila memiliki pengetahuan (informasi), status sosial dan kekuasaan. Dalam kontek pengembagan diri akademik, pengetahuan (informasi) merupakan faktor yang paling mendasar / penting untuk mendapatkan kebutuhan integrasi personal dan sosial. Untuk mendapatkan informasi manusia harus belajar dari berbagai pengalaman dengan cara

\footnotetext{
${ }^{20}$ Ball-Rokeach dan De Fleur dalam Jalaluddin Rakhmat. Psikologi.... hlm. 116

${ }^{21}$ Ibid. Littlejohn, Stephen W. Theories....hlm. 198
} 
berkomunikasi dengan media teknologi informasi atau pengalaman orang lain.

Kehadiran handphone untuk mengakses internet sebagai media komunikasi, para mahasiswaa memanfaatkannya untuk mendapatkan informasi sebanyak-banyaknya merupakan hal yang paling penting diera teknologi informasi. mahasiswa sebagai kelompok ilmiah, memiliki status sosial yang dapat diterima oleh semua pihak, baik dikalangan masyarakat kampus maupun luar kampus, sehingga dengan status sosial inilah yang mendorong untuk senantiasa meningkatkan pengetahuannya dengan mengakses informasi sebanyak-banyaknya dalam rangka proses mereaih perestasi akademik. Keinginan untuk mengakses informasi melalui internet merupakan media yang sangat penting, hal ini disebabkan karena ketersdiaan jumlah informasi yang dapat menunjang kegiatan perkuliahannya. Namun demikian bahwa informasi yang disediakan di internet sejatinya juga harus diperhatikan kesahihan informasinya sebab adakalanya informasi yang tersaji tidak bisa dipertanggung jawabkan. Hal ini terjadi karena adakalanya si penulis hanya iseng, dan bahkan hanya untuk membentuk opini masyarakat.

Seharusnya dalam proses pengembangan diri setiap mahasiswa harus mengubah sikap dan prilakunya dalam belajar dengan tetap menjadikan media informasi buku sebagai sarana untuk cross check terhadap informasi yang diperoleh di internet

\section{Bentuk Mahasiswa UIN Sulthan Thaha Saifuddin Jambi dalam mencari informasi baru di internet Melalui Media Handphone}

Ketersediaan sarana yang ada di internet berupa mesin penelusuran merupakan salah satu indikasi bagaimana internet memiliki serba keunggulan dalam proses pencarian informasi. Tersedianya fasilitas menyebabkan pola pencarian informasi di kalangan pengguna juga beragam. Ada yang senang dengan menggunakan fasilitas seperti google, Yahoo atau mesin penelusuran lain.

Pola pencarian informasi di kalangan mahasiswa UIN Sulthan Thaha Saifuddin Jambi lebih terfokus pada mesin penelusuran Google, Facebook, Youtube, Yahoo!, dan Wordpress bahkan kebanyakan para mahasiswa tidak 
menggunakan yang lain. Terfokusnya pada mesin tersebut lebih disebabkan karena kurangnya pengetahuan terhadap mesin penelusuran lain. Selain itu rendahnya pengetahuan terhadap metode penelusuran informasi menyebabkan proses pencarian tidak efektif dan efisien meskipun informasi yang diperoleh cukup memenuhi kebutuhannya. Teori pencarian informasi dikatakan bahwa individu akan mencari informasi melalui akses di media internet lebih bersifat insedentil, yang memudahkan, lebih familiar dan sumber informasi yang dikandungnya sesuai dengan kebutuhan individu yang menggunakannya. Pola pencarian mahasiswa UIN Sulthan Thaha Saifuddin Jambi pada umumnya yang sudah dianggap familiar dan dianggap tidak rumit. Mereka lebih senang menggunakan search engine Google karena search engine ini yang sudah familiar, padahal masih banyak search engine lain semisal, Deador, About, Lycos, Teoma, Altavista, atau situs lokal misalnya detikcom, Liputan6, Kaskus, BukaLapak, dan Kompas.com.

Selain itu, pola pencarian informasi pada media internet juga ditentukan seberapa kemampuan mahasiswa dalam memanfaatkan bahasa yang dikuasainya. Kemampuan menggunakan bahasa merupakan salah satu indikator dari penguasaan teknologi informasi dalam proses pengembangan diri. Berkaitan dengan kondisi mahasiswa UIN Sulthan Thaha Saifuddin Jambi dalam proses pencarian informasi di internet umumnya menggunakan bahasa Indonesia artinya sumber-sumber informasi yang didownload atau dibrowsing lebih bertumpu pada bahasa Indonesia, sementara pada bahasa lain tidak begitu sering digunakan. Meskipun ada beberapa mahasiswa yang menggunakan itupun juga didominasi oleh para mahasiswa yang memiliki kemampuan bahasa Inggris itupun sangat terbatas, dan umumnya adalah mahasiswa jurusan bahasa Inggris, sastra inggris dan beberapa mahasiswa dari jurusan lain.

\section{Harapan Mahasiswa UIN Sulthan Thaha Saifuddin Jambi dalam mencari informasi baru di internet Melalui Media Handphone}

Harapan merupakan aspek afektif yang ada pada diri setiap individu yang dapat mempengaruhi prilaku dan sikapnya dalam kerangka proses pengembangan diri. Teori harapan mengemukakan bahwa; 1) setiap individu 
percaya bahwa ia berprilaku dengan cara tertentu, ia akan memperoleh akan hal tertentu; 2) setiap hasil mempunyai nilai atau daya tarik bagi orang tertentu; 3) setiap hasil berkaitan dengan sesuatu persepsi mengenai seberapa sulit mencapai hasil tersebut.

Berdasarkan konsep di atas bahwa, prilaku tertentu akan menghasilkan hasil tertentu; hasil tersebut mempunyai nilai positif baginya; dan hasil tersebut dapat dicapai dengan usaha yang dilakukan seseorang. Jadi seseorang akan memilih sesuatu ketika ia melihat alternatif-alternatif, tingkat kinerja yang memiliki kekuatan motivasional tertinggi yang berkenaan dengannya. Dalam kaitannya dengan proses pengembangan diri bahwa orang akan termotivasi untuk mencapai suatu jika harapan-harapan yang ada pada dirinya seiring dengan realita yang dihadapi. Artinya harapan akan terwujud apabila kondisi yang ada disekelilingnya cukup membantu untuk mewujudkan harapannya. Setiap individu akan memiliki harapan apa yang dilakukan atau dikerjakan karena itu menurut McClelland bahwa harapan muncul seiring dengan keinginan, kebutuhan atau dorongan untuk menggapai sebuah perubahan yang lebih baik. Dalam proses pengembangan diri, setiap individu akan mengharapkan adanya perubahan yang positif terkait dengan status sosialnya.

Eduard Spranger menyebut inidvidu seperti mahasiswa di atas sebagai manusia yaitu prilaku yang suka berfikir, berfilsafat dan mengabdi pada ilmu. Yang diharapkan dalam hal ini adalah munculnya prilaku para mahasiswa yang suka membaca, senang berdiskusi mengenai dinamika pengetahuan dalam berbagai sudut, menyelidiki suatu kebanaran/ mengadakan penelitian, senang menjauh atau kesendirian daripada berbicara dengan orang lain secara iseng. Harapan-harapan seperti ini juga terungkap dalam proses perbincangan di kalangan para mahasiswa yang menginginkan adanya perubahan positif dalam mengemban amanah sebagai insan akademis. Namun pada prinsipnya, harapan tersebut sudah ditunjukkan oleh beberapa mahasiswa yang menjadikan media $e_{-}$mail, facebook, dll sebagai media untuk mengkomunikasikan harapan-harapan tersebut. Umumnya mereka berkomunikasi di seputar pandangan terhadap keilmuan, guyon-guyonan 
positif tentang arah kebijakan kampus ke depan, dinamika pengetahuan yang relevan dengan tugas dan keilmuan masing-masing.

Para mahasiswa UIN STS Jambi dalam hal ini, memiliki harapan dari proses komunikasi melalui media internet yang merupakan salah satu media akses informasi dalam kerangka menambah pengetahuan, pengalaman dan pergaulan mengharapkan adanya peningkatan prestasi akademik. Harapan yang ada dari proses komunikasi melalui media internet adalah berdasarkan penuturan dari beberapa mahasiswa yang diwawancarai. Selain itu para mahasiswa pada umumnya mengharapkan ada perubahan signifikan dalam menunaikan tugasnya yakni semakin memberikan kemudahan dalam proses pelayanan seperti konsultasi akademik dengan dosen, informasi dari akademik mengenai urusan mahasiswa, dan informasi-informasi yang sifatnya ilmiah baik sesama mahasiswa maupun dengan dosen dan karyawan.

\section{E. KESIMPULAN}

Berdasarkan deskripsi di atas menunjukkan bahwa; pertama, orientasi mahasiswa UIN Sulthan Thaha Saifuddin Jambi dalam memanfaatkan internet dengan memanfaatkan handphone sebagai media akases informasi berorientasi untuk menunjang kegiatan akademiknya seperti menyelesaikan tugas-tugas perkuliahannya, untuk menambah wawasan pengetahuan dan pengalaman, dan menghabiskan waktu dengan informasi hiburan. Adapun motivasinya adalah sebagai motif ingin tahu yakni dorongan untuk mengetahui hal-hal yang baru dapat menambah wawasan, berfikir secara sistimatis, berprilaku dalam menyampaikan ide, dan untuk menambah pengalaman empiris; motif berkompetensi; bersikap persepsionis; motif untuk berprestasi yakni dorongan untuk mengubah metode belajar; dan dorongan harga diri yakni dorongan untuk mengaktualisasikan diri, ingin memiliki peran, dan ingin diakui oleh masyarakat dalam dan luar akademis. Tujuannya adalah diversion yakni untuk melepaskan diri dari rutinitas dan masalah, sarana pelepasan emosi; personal relationship yakni persahabatan, kegunaan sosial, pergaulan luas, ajang silaturahmi, peneguhan kontak dengan keluarga dan lain-lain; personal identity yakni referensi diri, eksplorasi realitas, penguatan nilai, ingin memperkuat identitas diri, kepercayaan, stabilitas dan status individual. Bentuk dan metode pencarian 
informasi adalah melalui artikel, PDF. Sementara mesin penelusuran yang digunakan umumnya menggunakan Google dan Yahoo. Penelusuran hanya bersifat browsing dan download. Harapannya adalah; good behaviour seperti suka membaca, senang berdiskusi mengenai dinamika pengetahuan dalam berbagai sudut, senang menajuh atau kesendirian daripada berbicara dengan orang lain secara iseng. dan Competence yakni memiliki kemampuan yang kompeten dalam teknologi informasi yang tidak hanya memiliki kemampuan memahami teknologi informasi dengan berbagai perangkatnya.

\section{DAFTAR PUSTAKA}

Anonim. Kamus Besar Bahasa Indonesia. (Jakarta: Balai Pustaka, 1994)

Jalaluddin Rakhmat. Psikologi Komunikasi. (Bandung: Remaja Rosda Karya, 2002)

Basuki, Sulistyo. Teknologi Komunikasi Dalam Lembaga Informasi dan Perpustakaan. (Jakarta: Gramedia, 1992)

Choo, Detlor, \& Turnbull. Working the Web [microform] : An Empirical Model of Web Use. Microfiche. ([Washington D.C.]: ERIC Clearinghouse microfiches. 1999)

Djaali. Psikologi Pendidikan. Jakarta: Bumi Aksara, 2007)

Kadir, Abdul. Pengenalan Sistem Informasi. (Yogyakarta: Andi, 2006)

Littlejohn, Stephen W. Theories of Human Communication, ed ke-3. (Belmont, California, Wardsworth Publishing Company, 1989)

Moleong, Lexi. Metodologi Penelitian Kualitatif. (Bandung: Remaja Rosda Karya 2007)

Naisbitt, John. High Tech High Touch: Pencarian Makna di Tengah Perkembangan Pesat Teknologi. (Bandung: Mizan, 2001)

Poerwandari, Kristi. Pendekatan Kualitatif untuk Penelitian Perilaku Manusia, (Jakarta: LPSP3 Fakultas Psikologi UI, 2007) 
Rakhmat, Jalaluddin. Psikologi Komunikasi. (Bandung: Remadja Rosdakarya, 1998)

Reddick, Randy and King Elliot. Internet untuk Wartawan: Internet untuk semua Orang. (Jakarta: Yayasan Obor Indonesia, 1996)

Sptizberg. Brian H. Preliminary Development of a Model and Measure of Computer-Mediated Communication (CMC) Competence. (School of Communication San Diego State University, 2006)

Thomas J dan Misty E. Discovering Computer. (Jakarta: Gramedia, 2006)

Yuniar Supardi. Aplikasi Populer Handphone. (Jakarta: Eleks Media Kompetindo, 2009) 